答)今回検討した中ではそのようなことは感じなかった。

賢問)耳鼻麻生宮下：管電任を140kV大にすることで被曝の問題 も許容されるとしているが、どの程度軽減されたか，またその場合 低コントラスト分解能が落ちるのではないか。

答)管球の問題で実際の測定はしていない，今後状況が整えば測 定してみようと思う.

演題21はサブトラクションを利用することにより，スライスプ ロファイルを改善することができたという報告であった．スライス 厚改善にあたり，ワークステーション上での操作に何らかのfactor が介在していることは間違いない。どのような画像操作が行われた かが問題として残る.ワークステーション上での両像の作製はこれ から多く行われていくと思われるのでその点において非常に興味深 いものであった。

質問〉耳奛麻生宮下：サブトラクションの式を見る限り得られる 画像はsegmental reconの画像であるとしか思えないが。

答)ワークステーションに画像を送りサブトラクションをした.

その結果得られた画像がこのような特性をもっていた。

CT装置において性能評価を行う際，臨床を行っている立場で は，研究途中に急患が来たりとなにかと時間的制約があり，その中 で今回のような報告をしてくれた演者の方々には敬意を表したい. また、会場には多数の会員の方々にお集まり頂きこの分野の関心の 高さがうかがわれた. 今後益々この分野での研究が成されることを 期待する。

\section{8 高速嫘旋走直型CTによる肺寀検診施行のための基喏的検討} 勤医協中央病院 舩山和光，他 2 名

【目的】高速螺旋走查型CTの特徴として，時間的、空間的データか 連続していること，時間分解能が良いことなどがあげられる．近年 この特徵を利用して，肺癌の検診を行い，早期発見·早期治療につ なげたいとする樴運が盛り上がってきている。.今回われわれは， 高時間分解能，低被曝線量を目指した場合の画質の低下が肺野内の 病変の描出にどの程度影䇾するかを検討したので報告する。

【方法】胸部ファントームを用い，寝台移動速度，管電流を变化さ せ，肺野内結節の見え方を検討する。

\section{9 ヘリカルスキャンの実効スライス厚測定法の検討 NTT札幌病院 桑原貞俊，他 2 名}

【目的】へリカルスキャンにおける実効スライス厚の測定にはアルミ 板傾斜法・ロート状ファントム・らせん状ファントム・コイン状ファ ントム(コイン法)・エッジ法·微小小球体法などがある。われわれは コイン法を基本とし、微小小球体法とともにその材質形状の違いに よるSSPzの変化と測定上の問題点を提起する．また単位ステップ 関数より微分し、テルタ関数を求める手法よりSSPZを導出するエ ッジ法に関しても検討を加えたので報告する。

【結果】コイン法では蔓台移動位置によるSSPZのピーク位置のずれ と形状の変化が確認できた。 アクリル円柱によるエッジ法ではアラ イメントによる誤差が少なく良好な結果であったがthin sliceには 適用が難しい. steel wireによるものではアライメントの精度の問 題でthin sliceには良いが10mm thでは誤差が大きくなる. 微小小 球体法は，再現性簡便性には優れるがその大きさによりSSPzは大 きく変わる。

\section{0 thin slice重ね合わせ法の物理評価と臨床底用} NTT札幌病院 桑原貞俊，他 3 名

【目的】thin sliceの重ね合わせにより，頭蓋底のHousnfield dark spaceなどのartifactが改善されることはよく知られている.しか し，scan時間の增加による時間分解能・スループットの低下が問題 となるとともに撮影条件の選択によっては患者の被曝を増加させる 危険をもっている，われわれは，5mm conventionalと加算イメー ジのノイズ量(S/N)を同一となるよう近似式より撮影条件を決定. 最適化し，この条件下での密度分解能・実効スライス厚を測定しテ ーブル移動速度およびリコンピッチについて検討した

【結論】最適化した撮影条件により加算イメージの密度分解能はconventionalと等しい.SSPzよりへりカルピッチは2:1とし，時間分 解能をconventionalと同等にすることが可能となった。脳底部のほ かに鎖骨上部，腰椎などへの適用の有用性が確認できた。被曝に関 してはビーム幅の狭小化およびらせん犹に照射されるため同一点に 連続的に照射されるコンベンショナルと比較し管球出力を約1.5倍 としても少なくなると思われる.管球出力は電流・時間ともに增加 させなくてはならないため負荷の問題が残るが管電圧を140kVとし 電流を下げることにより解消することができるであろう.

\section{1 ヘリカルCTのスライス厚改善}

NTT札幌病院 川原聖樹，他 3 名

ヘリカルCTは従来のコンベンショナルCTに比べ，時間分解能に 優れている．しかしS $/ N$ ，スライス厚、コントラスト分解能等が劣 っている. 特にへリカル・ピッチを上げてスキャンするとその傾向 は顕著となる.そこでわれわれは異なる画像再構成法で得られた画 像を用いてスライス厚を薄くする(Z軸方向の分解能改善)ことを試 みた．通常のヘリカル画像(以下，HEL)からsegmental recon(以 下, SEG)された画像をサブトラクションする. 次にHELから (HEL-SEG)の画像をサブトラクションする.このようにして得ら れた画像 (以下H- (H-S)) に対し比較·検討を行った。スライス厚 は, HEL, H-(H-S), SEGの䫀に薄くなる.しかし, SEGは高吸 収体からのアーティファクトやノイズに間題があり実用的ではな い. H-(H-S) は手間がかかること以外に大きな問題もなくへリカル スキャンのスライス厚改善として有効な手段であった。

\section{情報管理}

座長 (株)ジェイマックシステム 熊木康雄

本セッションでは，医療情報のディジタル化に拍車がかかってい る今日，実運用を踏まえ構案したネットワークシステムに関する3 題の演題が発表された．演題22は，ネットワークシステムの中で も，施設間を結ぶ画像伝送ネットワークシステムについての発表 で, 演題23.24は同施設内での院内(部内) システムの搆䓩に関する 発表であった。演題22はセントラルCIクリニックの発表で，CT. MRの検査専門施設として開院した同クリニックで構築した画像伝 送による画像診断支援に主体をおいたシステムについての発表であ り，発表內容としては，システム構築の目的・システムの概要·実 運用上でのデータ発生量・画像伝送上での転送実速度・実運用を通 しての間題点-今後の課題/間題点と簡溸にまとめられ理解しやすい 内容であった。

演頑23·24は北海道大学の発表であり，演題23では管理対象と なるCT·MR·DSAの画像情報の管理(ファイリング)についての発 表であり，演題24では、画像情報の管理に付随しての放射線治癔 における情報管理について発表であった．北海道大学でのPACSの 構築は，世界的にも時代に先駆けて運用構築されてきたことは，周 知の事実であるが，今回の発表では，これまでの様々な経験を踏ま え，より実用的なシステムの構築を图っていくうえでの留意点を中 心とした発表になっており，演題24に至っては，さらに放射線治 瘖部門に限ったシステム構筑上の留意点について，その詳細につい ての発表であった。

現在，法的問題も踏まえ，画像管理が非常に重要な認識のもと検 討されているが，これらシステムの構築については，各施設ごとに また構築目的により様々な形態が考えられ，今回の構築内容が基本 になるとは考えつらい。しかし，発表内容にあったシステム構築の ための留意点および各種実測データ(転送スピード等)，さらには提 示された問題点等は，今後他施設でシステム構娼を検討していくう えで、十分参考となる内容であったと評価できる. 今回発表した 3 題に関しては，構築運用されてからまだ日が浅いようであるため， 今回の発表をもとに、問題点への対応および今後の拡張など、続報 を期待したい，さて，今回の発表内容からしても，情報管理システ ムの構築については，まだまだ検討していくべき問題点が多いと考 えるが，十分実用的なシステムが構築できる時期にきていることも 明確であるようだ.

最後に1点だけ付け加えるなら，これらシステムは，われわれ医 療人として，最終的には患者さんの利益につながるシステムとして 構築しなければいけないことを、忘れてはいけない，あながち、こ のようなシステムは医療人の業務効率の向上が大きく目的とされる ケースが多いが，業務効率の向上が患者さんへの利益につながるこ とを常に念頭におき、医療情報の本質を十分考慮された上で，各施 設で様々なシステムの構築を進めていっていただければ幸いであ る.

22 ISDNを利用した高精細画像診断支援ネットワークシステ ムの試み

医療法人禎心会セントラルC|クリニック

山岸妃早代，他 7 名

【目的】本年 4 月より総合画像診断を目的とした，院内LANおよび 北海道大学医学部附属病院放射線科、禎心会病院とのネットワーク システムを順次構築してきたが，本システムの利点・問題点等を検 討したので報告する. 